\section{Original} Article

\begin{tabular}{|l|}
\hline Access this article online \\
\hline $\begin{array}{l}\text { Website: } \\
\text { www.ajobe.org }\end{array}$ \\
\hline DOI: \\
10.4103/1817-7417.119954 \\
\hline Quick Response Code: \\
\hline
\end{tabular}

Address for correspondence: Madeleine C. Fombad Senior Lecturer, Department of Information Science at University of South Africa (UNISA), Pretoria, Gauteng, South Africa E-mail: fombadm@yahoo.com

\title{
Accountability challenges in public-private partnerships from a South African perspective
}

\author{
Madeleine C. Fombad
}

Senior Lecturer, Department of Information Science at University of South Africa (UNISA), Pretoria, Gauteng, South Africa

\section{ABSTRACT}

One of the potential benefits of public-private partnerships (PPPs) is its capacity to enhance accountability. Although the South African government has made several efforts to address the need for fairness in service delivery and improve accountability in procurement, accountability remains a challenge in PPPs in South Africa and most other countries. If PPPs are to play their role in infrastructure development and service delivery, and thus serve public interests, the problem of accountability must be addressed. This paper attempts to identify some of the accountability challenges in PPPs, together with a literature review, to provide some future perspectives on PPPs in South Africa.

Key words: Accountability, democracy, developing economies, millennium development goals, publicprivate partnerships, service delivery, transparency

\section{INTRODUCTION}

Since 1999, the South African government has, like many other countries, been exploring better ways of financing and managing pubic capital assets, serve the public interest, and deliver public goods and services through public-private partnerships (PPPs). One of the potential benefits of PPPs is its capacity to enhance accountability by clarifying responsibilities and sharpening the focus of key deliverables (Heymans and Schur, 1999). However, there are several arguments suggesting that PPP may, in fact, reduce accountability and undermine public control (Siddiquee, 2011; Reeves, 2011). Although the South African government may have taken a firm step towards addressing the need for fairness in service delivery and improving accountability in procurement and tender processes, the latter remains a challenge in PPPs. If PPPs are to play an important role in infrastructure development and service delivery and thus serve public interests, the problem of accountability will need to be addressed. Very few studies on PPPs in South Africa have dealt with the issue of accountability.

This paper identifies some of the accountability challenges in PPPs, and draws upon an extensive international literature review to provide some future perspectives on
PPPs in South Africa. The first section briefly looks at PPPs in South Africa. The second section examines the different meanings of accountability. The third section identifies accountability challenges in PPPs. The fourth section suggests some future perspectives on accountability in South Africa, and the paper ends with some concluding remarks.

\section{PPPs in South Africa}

Although some forms of PPPs, such as private tax and toll roads, have existed since the Roman Empire, some uncertainty remains as to what exactly this concept entails. It is often referred to and defined in different ways depending on the author, the jurisdiction and the context. It is also important to note that PPPs go by different names in different countries. In Australia, for example, it is referred to as private finance projects (PFP), and in the United Kingdom, it goes by the name privately financed initiatives (PFI). In general terms, PPP refers to a variety of cooperative arrangements between the government and the private sector or non-governmental organisations to improve infrastructure networks and enhance service delivery by means of out-contracting, out-sourcing, donating or privatising public goods. This paper focusses on the narrow definition of PPP, according to which the private sector plays a greater role in decision-making and risk assumption. To this end, these types of 
PPPs are distinguished from the aforementioned forms of procurement such as out-contracting, out-sourcing, donation and privatisation. In the South African context, this usually refers to partnerships that have been registered with and approved by the National Treasury. South African Treasury Regulation 16 (2004) defines this type of PPP as a contract between a government institution and/or municipality and a private party, where the private party performs an institutional function and/or uses state property in terms of output specifications, according to which substantial financial, technical and operational risks are transferred to the private party, while the private party benefits through unitary payment from a government budget and by receiving user fees.

Although this definition highlights the issues of risk and institutional function typical of PPPs, it raises several questions relating to the accountability and management of PPPs. First, the reference to the substantial financial, technical and operational risks that are transferred to the private sector needs to be clarified. This is because, in reality, the government ultimately bears a substantial part of the risk. Also, consistent with international norms, the purpose of risk allocation is to ensure that the allocation of defined risk is optimum during procurement. Secondly, the definition does not specify the relationship beyond contractual commitments.

Two other definitions are relevant to the understanding of PPPs within the context of this paper. First, a PPP is defined as a partnership between the public and private sectors, pursuant to a long-term contractual agreement involving high capital cost, a lengthy contract period, and risk-sharing (Public Accounts Committee New South Wales Parliament, 2006). The second definition specifies relationships beyond contractual commitments, and includes elements such as trust, mutual commitment, and social and community obligations. Bovaird (2004) defines PPPs as working arrangements based on a mutual commitment over and above that implied in the contract between the public and the private sectors. Evidence shows that PPPs work well where there is commitment and trust between the government and the participating enterprises (Rein and Stott, 2009).

On the basis of these two definitions, this paper regards PPPs as long-term contracts drawn up between the government and the private sector. Such contracts are based on mutual commitment, and trust, risks, rewards, resources, skills, expertise and finances are shared. PPPs range from simple contracts, known as service contracts, to long-term contracts, known as concessions (Novia Scotia Cooperation Agreement, 1996; Armistead and Pettigrew, 2004; Grimsey and Lewis, 2004, Coulson, 2005; Sedisa, 2008).
A number of PPP projects have been concluded, involving roads, water, hospitals, schools, transport, accommodation, healthcare, ecotourism, education, social development, correctional services and railways. Amongst these are the Inkosi Albert Luthuli Hospital, Free State Social Grants Information, technology for the Department of Labour, and the Department of Trade and Industry campus concessions. Other operational PPPs worth mentioning are the Gautrain Rapid Rail Link that was responsible for the design, construction, operation and maintenance of this public rail transportation system, Fleet Management, the Western Cape Rehabilitation Centre, Lentegeur Hospital, the renal dialysis service at Polokwane Hospital, and Port Alfred and Settlers hospitals.

Some of the PPPs concluded in South Africa have counted among the most successful in sub-Saharan Africa. Statistics from the World Bank Private Participation in Infrastructure (PPI) database reveals that in the period 1999-2003, South Africa was the leading African country in PPP infrastructure (Thomson, 2005). Similar to most developing economies, South Africa finds itself in the first stage of the PPP maturity scale, which Deliote and Touche (2006) refer to as the developing market. In South Africa, the processes for the evaluation and establishment of PPPs are similar to those in other countries, such as the United Kingdom, Canada, the Netherlands and Australia. The National Treasury regulates PPP through its dedicated PPP unit at the national, provincial and local levels. It evaluates and approves PPPs and provides active support throughout the process to ensure affordability, value for money and the appropriate risk transfer in the PPP cycle, from its inception through to the feasibility study, procurement and development.

Nevertheless, the credibility of cost-benefit analyses to determine value for money in PPPs has generally been questioned, because no active steps are taken to ensure that PPPs meet the value-for-money test. The main models of PPP already in operation in South Africa are the design, finance and operate (DFO) model, the design, finance, build, operate and transfer (DFBOT) model, the design and transfer (DT) model, the build, operate and transfer (BOT) model, as well as equity partnerships (Treasury Regulation $16,2004)$.

Government's support for the PPP approach is evident: It is regularly promoted in annual policy, as well as in budget and presidential speeches, and is considered an integral component of the state's strategy for the growth provision for services and infrastructure.

However, while presidential and governmental support for PPPs remains strong, leadership in this field is still considered to be weak (Dach, 2010). This is evident in the inability of the public sector to bring the many 
planned projects to fruition. For example, since 2000, on average, only two PPPs have been successfully concluded per year on the national and provincial levels. The process can take $2-3$ years to completion, and many have been deregistered (Aeillo, 2009). The South African PPP unit recorded a total of $21 \mathrm{PPP}$ projects that have been deregistered, with 60 more in the pipeline by the end of 2010 (National Treasury, 2011; Aiello, 2010). Furthermore, the South African Constitution and other pieces of legislation at the national and provincial levels, such as the Public Finance Management Act of 1999 (the PFMA), Treasury Regulation 16 of 2004, the Municipal Systems Act of 2000 (the MSA) and the Municipal Finance Management Act of 2003 (the MFMA), emphasise the need for transparency and accountability in procurement. Yet, there are no visible functional mechanisms in place to ensure that the robust PPP legislation is properly interpreted, understood and implemented. These laws, which are supposed to put South Africa on the right path towards a coherent regulatory regime, are sometimes contradictory, requiring careful interpretation. Examples are the MFMA (2003) and the MSA (2000), both of which require feasibility studies to be undertaken before a municipality forms PPPs. While the period prescribed for feasibility studies in Section 78 of the MSA is approximately 2 years, in the MFMA (2003), an average of 6 months is stipulated. Consequently, a wide variety of partnerships have emerged over time, some adhering strictly to the terms of the law, others established within the law, but outside of the structures prescribed by the different sections of legislation on PPP (Mitchell, 2007; Levinsohn and Reardon, 2006). There are many public-private contracts in existence, in different forms, such as those of out-contracting, leases, and build-own, and transfers that are not registered with the treasury because formal procedures and regulations are cumbersome.

Other accountability issues have also affected the development of PPPs. There is little evidence of external auditing of PPP activities by parliament. Just how far the Auditor General's reports go in achieving the desired effect of correcting aberrations is questionable. It was only recently, from 27 to 29 July 2011, that the Parliamentary Standing Committee on Public Accounts conducted an oversight visit to prison PPPs in the Free State, the Northern Cape and Limpopo (Parliamentary Communication Services, 2011). This was a long-overdue follow-up on the Auditor General's three qualified audit opinion reports, issued in 2007/2008, 2009/2010 and 2009/2011. Also, the dedicated PPP unit, which is responsible for monitoring and implementing PPP contracts and providing policy guidance, technical support, capacity-building and funding has been experiencing a series of challenges. The development of living documents within this unit, such as the PPP Manual, as well as documents on standardised PPP market provisions, municipal service delivery and PPP guidelines for municipal PPPs, appears to have stalled in 2005. The standardised PPP market provisions introduced in 2004 are currently still undergoing revision (Aiello, 2010). It is, therefore, clear that notwithstanding the abundance of regulatory safeguards and top-level support for PPP operations, the issue of accountability remains a concern. But what exactly is accountability in PPPs? The next section provides an overview of the meaning and concepts of accountability in the context of PPPs.

\section{ACCOUNTABILITY}

Accountability is a complex, elusive, abstract, multifaceted and contested issue that can be approached in different ways, depending on the role, institutional context, era and political perspective. Four different approaches to accountability are presented in Figure 1. The first is the traditional, hierarchical one of the relationship between an agent and a principal, in which an agent with delegated authority has a personal obligation to answer to the principal for the performance of delegated responsibilities. In this regard, accountability in public administration has been defined as an obligation on the part of public officials to report on the usage of public resources and to answer for failing to meet stated performance objectives (Armstrong, 2005).

Mulgan (2003) adds a social dimension to the principalagent approach. He defines accountability as a social interaction involving rights on the part of the account holder and obligations on the part of the actor to justify and explain their conduct. Bovens (2007) builds on the social dimension by describing accountability as a relationship between an actor and a forum, in which the actor has an obligation to explain and justify his or her conduct to the forum, which may, in turn, pose questions and pass judgement. The relation between sovereign and subjects, forum and actor, actor and account holder is the defining element

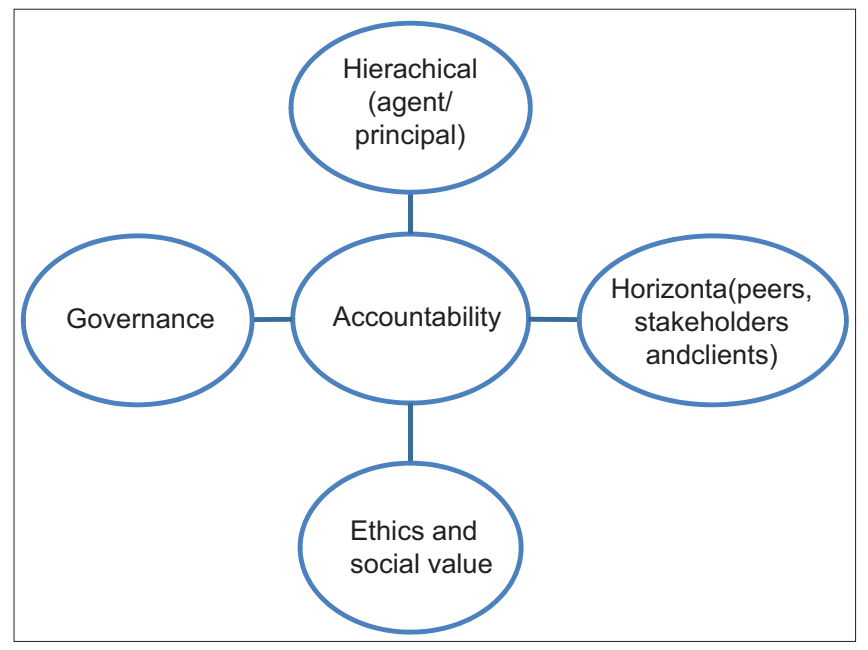

Figure 1: Approaches to accountability in PPPs 
in the principal-agent approach. Within the new public management system $(\mathrm{NPM})^{1}$, the agent-principal relation is seen as accountability-based performance management in the form of monitoring, auditing, benchmarking and evaluating in order to enhance performance (Dubnick, 2005; Demirag and Khadaroo, 2011). It is considered a tool for enhancing government's ability to deliver public goods and services more effectively and efficiently while ensuring value for money.

The hierarchical approach to accountability in PPPs reflects structures in which individuals perceive themselves as responsible for reporting, justifying or explaining their actions to others, and being liable to sanctions in the event of errors and shortcomings. Some of the key institutional accountability structures that have been modified and built upon over the years are bureaucratic, political, legal, contractual, market, communal, managerial, professional, administrative and collaborative accountability mechanisms (Romzek and Dubnick; Sinclair, 1995; Stone, 1995; Deleon, 1998; Flinders, 2003; Mulgan, 2003; Dowdle, 2006; Mashaw, 2006; Scott, 2006; Boven and Schillemans, 2009; Koliba et al., 2011). For example, citizens in a democratic society have an obligation to hold elected officials accountable, through communal accountability, for the way in which they formulate and implement contracts and provide public goods and services. Public officials and their private partners are also legally bound by the contract and the rules of law. Furthermore, elected officials and administrators are obliged through political accountability to report on their performance of the duties that their responsibilities entail. However, the hierarchical focus on the agent's accountability to the principal and on formal sanctions does not easily apply within the context of PPPs. The reason for this is that PPPs involve different stakeholders with different interests working together to achieve a common objective (Morth, 2007). Jones and Stewart (2009) argue that shared accountability in PPPs is inclined to become, in practice, joint irresponsibility, where no one is accountable, due to the blurring of public and private sector responsibilities.

Therefore, the second approach to accountability, which is presented in Figure 1 as horizontal accountability, has been advocated as broader, more practical and realistic because it facilitates discussions on how multiple expectations generated within and outside the partnership - often together with conflicting objectives - can be managed in a non-hierarchical way (Romzek and Dubnick, 1987; Kearns, 1994; Acar et al., 2008; Willems and Dooren, 2011). This type of accountability is typical of PPP agreements because it deals with the management of expectations of the multiple, complex and conflicting undertakings of stakeholders in such a way as to ensure mutual influence, mutual accountability, and transparency, and equal participation in decision-making.
The third approach to accountability, which is also presented in Figure 1, refers to accountability at an individual level. It is about having a conscience or a sense of moral responsibility about one's actions. It also involves adherence to legislation and codes of conduct, and the possession of inherent dispositions, attitudes and virtues. One example is the Nolan Committee's seven principles of public life (Chapman, 2000:230-231), which provide a valuable framework for evaluating the ethical behaviour of public officers. These principles are selflessness, integrity, objectivity, accountability, openness, honesty and leadership.

The fourth approach to accountability is depicted as synonymous with loosely defined political desiderata, such as good governance (Mulgan, 2000; Behn, 2001; Dubnick, 2005). The overarching requirement for good governance in procurement, which is consistent with international norm and standards, is captured in Section 217 (1) of the Constitution of the Republic of South Africa 108 of 1997. It states that when an organ of state in the national, provincial or local sphere of government or other institution identified in the national legislation contracts for goods or services, it must do so in accordance with a system that is fair, equitable, transparent and cost-effective. Clifton and Duffield (2006) define governance in PPPs as achieving and improving long-term service outcomes. According to Osborne (2000), PPPs are a new form of governance and legitimacy involving the public and private sectors. Within the NPM, PPPs provide a novel approach to delivering goods and services to citizens, based on the mode of management and governance, and are considered to be a policy tool for enhancing governance effectiveness (Bovaird, 2004; Brinkerhoff, 2007; Hodge and Greve 2005). The United Nations Economic Commission for Europe (UNECHE, 2008) outline the following seven principles for promoting good governance in PPPs: coherent PPP policies, strong enabling institutions, a legal framework, cooperative risk-sharing and mutual support, transparency, putting people first and achieving sustainable development.

The above four approaches to accountability all make a useful contribution towards our understanding of accountability in PPPs, as illustrated in Figure 1.

Hierarchical accountability serves as a check and motivation for holding those in PPPs answerable. It also includes formal hierarchical processes such as performance management, monitoring outcomes-based PPPs and reporting to parliament. However, relationships among participants in PPPs cannot be reduced to principal-agent relationships only, due to the multiple accountability relations that exist with diverse stakeholders. PPPs, therefore, stretch this traditional mode of accountability by presenting horizontal relationships, where government shares its 
responsibility with private entities involved in government decision-making and programme delivery. Furthermore, accountability in PPPs is also influenced by ethics and social values. The next section provides an overview of some of the accountability challenges in PPPs, and relates them to the South African context.

\section{ACCOUNTABILITY CHALLENGES IN PPPS}

Johnstone and Kouzmin (2010) identify the following as accountability issues fundamental to PPPs in Australia: Underbidding to win a tender, optimistic forecast to tariff, risk allocation, the higher cost of private capital versus government finance, the lack of disclosure and transparency, and citizen distrust of infrastructure development through PPPs. In this section, similar accountability challenges that are experienced in South Africa are discussed. Amongst these are a lack of public consultation and transparency, corruption, a lack of competition, accounting issues, ineffective contract management, failure to monitor performance, and failure to ensure value for money and equitable risk allocation.

\section{A lack of public consultation}

Although PPPs are important long-term societal investment projects, people are often alienated from the decision-making process. Negotiations between the public and private partners are often conducted in private settings with little input by citizens on the grounds of "commercial confidentiality," "propriety rights" or data protection, which are seen as grounds for secretiveness in partnerships (Roberts, 2002; TD Economics Special Report, 2006). Faced with public scepticism towards PPPs in Canada, the government withdraws at the first sign of controversy (TD Economics Special Report, 2006). In South Africa, the inception stages of a PPP require the institution to register the project with the relevant treasury, to appoint a project officer and a transaction advisor, to receive and evaluate transaction advisor bids, and to finalise and sign the contract with the transaction advisor (PPP Manual, 2004). There is no mention of public consultation. The Gautrain Rapid Rail Link project has been criticised for lack of significant public consultations and legislative debates before it was approved and put to tender (Stephen, 2005).

\section{A lack of transparency}

Transparency refers to the public's unfettered access to timely and reliable information on the decisions and performances in the public sector (Armstrong, 2005). The non-disclosure of PPP contracts to the public raises issues of accountability, and could compromise perceptions of the government's integrity. Theoretically, PPPs are legally binding and largely standardised contracts that are supposed to increase transparency in performance, costs, risk, time frames and output specifications. However, 55\% of respondents in a survey by Business in Vancouver on PPPs in British Columbia revealed that PPPs are not transparent about procurement, funding or operations (Petrozzi, 2008). In British Columbia, the practice of keeping value-for-money reports out of the public domain until well after the point of no return raises serious questions about due process and transparency during the procurement process (TD Economics Special Report, 2006).

The South African PPP unit provides superficial, inconsistent disclosure of PPP information online through the PPP Quarterly. The last quarterly report was published in December 2010. The information provided is limited to the name of the project, the government institution responsible for the project, the PPP type, the duration of the contract, the date of financial closure, private partner $(\mathrm{s})$, financing arrangements, transaction government advisors, the value of the project, the capital value of contracts signed to date, the procurement undertaken and the benefit to government (National Treasury, PPP Unit, 2009).

The leader of the South African opposition party, the Democratic Alliance (DA), called for the Gautrain Rapid Rail Link contract to be made public to reveal the province's real annual subsidy costs, in order to assess the options to save transport in South Africa (Campbell, 2011). Campbell laments that too much has been done in secret, and that poor planning has cost the government dearly. For example, the government disclosed only the cost estimates for the Gautrain Rapid Rail Link, which ballooned from R3.5 billion to R4 billion in 2000 to R30.462 billion in 2011. A review by the Correctional Services Minister highlighted a number of financial and operational problems that have been experienced with the PPP model, amongst which is the fact that bids are not open or evaluated (Venter, 2011). The need for sound procurement procedures, pre-project analysis, a high level of public consultation around the proposed development and discussions around costs has recently been emphasised (Creamer, 2012).

\section{Corruption}

Corruption has been a serious handicap to public procurement projects. Generally speaking, corruption is the abuse of entrusted power for private gain at the expense of the public interest. It may result in resource misallocation, a reduction in investment and competition, unresponsive policies, poor administration, unemployment, exacerbated poverty, and lack of transparency (Center for International Private Enterprise, 2011). The United Nations Development Program (UNDP, 2004) refers to corruption as monopoly plus discretion minus accountability, integrity and transparency.

As in most other African countries, in South Africa, the tendering process is still perceived to be riddled with corrupt practices in what has become known as tenderpreneurship. Although the criteria for PPPs are complex and subject to 
Treasury Regulations (Treasury Regulations, 2004) and the Code of Good Practice for Black Economic Empowerment in PPPs (PPP Manual, 2004), PPPs still offer greater latitude for manipulation by companies and government officials that cannot easily be spotted by either the public or anticorruption systems. For example, the former South African Minister of Transport resigned as a director of First Rand Bank in 2003, after it was alleged that he accepted gifts and payments of more than R500,000 from a former African National Congress fundraiser whose company was part of the winning N3 toll road consortium (West, 2003). A 25-year concession planned by the Kenyan government in 2004 for sections of its road network that formed part of the Northern Corridor (a transport corridor linking the Great Lakes counties of Burundi, the Democratic Republic of Congo, Rwanda and Uganda to the Kenyan seaport of Mombasa) suffered a setback following evidence of an attempted diversion of funds (Farlam, 2005).

Corruption remains one of the 20 key problems experienced by PPPs, according to the PricewaterhouseCoopers report on the Port Klang Free Trade Zone PPP in Malaysia (Beh, 2010). The effectiveness of the role played by an independent transaction advisor in reducing corruption levels in PPP deals is yet to be ascertained. It is very common for connected friends and relatives of politicians to be awarded lucrative supply contracts, despite submitting inferior bids and offering high prices and poor expertise. For example, suspicions have been expressed about the probity of the contracting process surrounding the Gautrain. There have been allegations that Bombardier, one of the lead partners in the Bombela consortium (consisting of Bombardier, Bouygues Travaux Publics, South African civil contractor Murray and Roberts, and strategic partners), agreed to pay hundreds of millions of rands to Tunisian arms and infrastructure "fixer" Youssef Zarrouk for his help in securing the contract. Zarrouk was to pass the money to the influential businessman and former Robben Island prisoner, Peter-Paul Ngwenya, in return for his help in lobbying on behalf of the company (Mail and Guardian, 2012). Although allegations of bribery have been refuted and there is no evidence of the money having passed to other politicians with the power to influence the bid, the fact that Ngwenya acknowledged receiving part of the money suggests that money was exchanged for political influence. In 2009, the South African Finance Minister expressed concerns about the number of government tenders that had become tainted by corruption, and lamented the pervasive influence of the culture of gift-giving, wining and dining, and all manner of enticements (Creamer, 2011). Recently, the Public Protector observed that poor management of tender systems will deprive the government of money needed to deliver on its antipoverty promises (Galway and Maphumulo, 2011).

South African black empowerment deals have been affected by "fronting," where companies appoint nominal Black directors or shareholders to win contracts that are, in fact, managed and owned by White people. Despite the guidelines contained in the Code of Practice for Black Economic Empowerment in PPPs (PPP Manual, 2004) on how to minimise fronting in feasibility and procurement processes, the practice continues unabated.

\section{A lack of competition}

Pollitt (2005) remarks that there are very few bidders for public finance initiative projects in the UK, due to the high cost of bidding, projects being awarded to well-connected politicians rather than to those who can add value to the economy, and only those who have money and own big companies tending to participate in these partnerships. Similarly, Cheung et al. (2009) observed that small, local companies are unable to compete with bigger companies, and that the same contractors tend to be successful repeatedly in winning bids. The same can be inferred from South African PPPs, where competition is more of perception than reality. It is alleged that the early PPP prison contracts were generally regarded as overpriced, because the government did not maintain the competitive tension for long enough (Kelman, 2001). The fact that the current Minister of Economic Development emphasises the importance of promoting competition in PPPs (Creamer, 2012) makes it questionable whether the National Treasury oversight unit, formed in 2000, has succeeded in enhancing the level of competition. Despite the South African government's stated policy of advancing black economic empowerment through PPP projects, and the related Code of Practice for Black Economic Empowerment in PPPs (PPP Manual, 2004), black companies are still faced with challenges such as a limited pool of black equity, a lack of experience and skills, too little capital and high transaction costs. The issue of competiveness is acute in long-term contracts, where the successful bidder becomes the monopolist supplier to the government. Burger (2004) observes that given the government's interest in seeing PPPs succeeds, there is a risk that the government may become vulnerable to private parties' demands to renegotiate the terms of contracts in their favour, thus undermining PPPs' value for money.

\section{Accounting issues}

One of the most significant accounting issues in the context of PPPs is off-balance-sheet financing, whereby the government does not record increases in debt or asset level for the required infrastructure (Walker, 2003; Baker, 2003; Fussell and Beresford, 2009). Off-balance-sheet financing is based on the macroeconomic policy of appropriate debt to gross domestic product ratios. Most governments have moved away from the cash-based accounting method, where investment in government infrastructure had a massive impact on a government's balance sheet, to accrual accounting, where upfront capital and operating costs are paid throughout the life of an agreement (Pina, 2001; 
Fussell and Beresford, 2009; Sciulli, 2010; Forrer et al., 2010). The argument in favour of "off-booking financing" is that governments can build new infrastructure without incurring new debt. It appears theoretically sound at the practical level, because it provides governments with a means of escaping tight constraints imposed by fiscal targets, and public and parliamentary scrutiny. However, the reality is that governments are still incurring debts, and are committing themselves to payments that will still have an impact on the budget, even though these do not show on the books. Newberry and Pallot (2003) argue that PPP commitments in New Zealand, which are excluded from public sector liabilities and estimates and, therefore, are not reported to parliament, burden future generations of taxpayers and commit future governments. Mayston (1999) and English and Guthrie (2003) reached similar conclusions about PPPs in Australia and the United Kingdom. For example, even though the Gautrain Rapid Rail Project manager argued that government could expand its spending on infrastructure without increasing the burden on the fiscus (Van der Merwe, 2007), the expenses incurred for the Gautrain have increased the burden on the fiscus. As mentioned above, the initial cost estimate for the Gautrain was from R3.5 billion to R4 billion in 2000, when the project was initially announced in South Africa. This figure was revised upwards to $\mathrm{R} 7$ billion for purposes of the environmental impact assessment process in 2003, and was revealed as having reached R20 billion in 2005, after the successful bidder for the project had been announced and a contract had come into existence (Cox, 2005). As of June 2011, the estimates stood at R28.1 billion, and towards the end of June, it was revealed in the Gautrain Management Agency's (GMA's) $19^{\text {th }}$ Quarterly Progress Report that the cost had escalated to R30.462 billion (Flanagan and Serrao, 2011). Blacke (2004) observed that it may also be possible for the government to underestimate the cost of the project and the revenue earned from the project, and this may be a recipe for disaster, resulting in unnecessary cost to the government and future generations of tax payers. Furthermore, the British Parliament's Public Account Committee Report (2011) on private finance initiatives for hospitals revealed that the off-balance-sheet nature of PPP contracts favours a move towards PPPs, and thus, creates a potential bias in the policy environment. The choice to apply PPPs should make economic sense and promote effectiveness and value for money, and should not be opted for because government wants to avoid on-budget spending. Off-budgeting is not a panacea.

In this regard, the International Monetary Fund (IMF PPP, 2004) expressed concerns about the lack of fiscal accounting and reporting structures within PPPs. It revealed that governments tend to use PPPs as a means to bypass spending control and to move public investment off-budget and debt off the government balance sheet, while the government still bears most of the risks involved and faces potentially large fiscal costs. It has been observed that the accounting standard setters were simply not ready for the rapid uptake of PPPs by the government, resulting in questionable accounts reporting techniques (Fussell and Beresford, 2009; Sciulli, 2010). There are still questions regarding how governments could assign capital costs to private-partnership payments, because capital and operating costs are combined into a unitary payment. The Comptroller General in British Columbia (British Columbia, Ministry of Finance Budget and Fiscal Plan, 2008) ruled that capital cost should include construction cost, interest incurred during construction, as well as project management cost, and that it should show up as any other capital asset, while project-operating payments should be recorded as contractual obligations in a note accompanying the financial statements.

It is sometimes better for the government to increase its debt levels and fund the projects itself than to sign PPP agreements, because of the long-term cost that the government may incur. The British Parliament's Public Account Committee report (2011) on private finance initiatives for hospitals revealed that public finance initiatives ultimately cost the government more, while enriching the private sector, with profits varying from 50\% to $200 \%$.

\section{Ineffective contract management}

Generally, PPP projects consist of demanding and complex contractual agreements for the construction of a facility and for service maintenance, which may stretch to more than the average tenure of a public manager. Sciulli (2010) refers to these contracts as "bundling of services." Incomplete contracts that do not specify the desired output of projects become problematic during the operational phase, which involves the transformation from project inception to project delivery. For example, in the case of the Gautrain, disputes have arisen between the public and the private party concerned as to who is responsible for repairing water ingress on the leg between the Rose bank and Park stations, because it had not been specified in the contract (Flanagan and Serrao, 2011). In addition, the high-speed rapid rail commenced its operation over a month past the extended starting date of 28 June 2011 that had been specified in the contract. Similarly, in the UK, the failure of the Metronet PPP to operate 9 of London's 12 underground lines is largely due to poor contract structuring, where the costs of operations were not adequately predicted. In Sydney, Australia, the Cross City Tunnel PPP encountered similar difficulties.

\section{A failure to monitor performance}

Although procurement in PPPs may appear to be more accountable than conventional procurement, because payment is linked to performance, studies show that the long-term concession period renders performance 
claims tenuous. Little thought tends to be given to the management and evaluation phases of PPPs. This may be partly due to the pre-contractual focus of the PPP unit and the legislative vacuum in this area. Treasury Regulation 16.7.1 (2004) provides for the following: "The accounting officer or accounting authority of the institution that is party to a PPP agreement is responsible for ensuring that the PPP agreement is properly implemented, managed, enforced, monitored and reported on, and must maintain such mechanisms and procedures as approved in treasury." In reality, the institution's accounting officer does not have much authority over the private party because the private party does not form part of the government's democratic chain of command. Also, there is no express provision for a monitoring and evaluation framework. The Tanzanian PPP Act 18 of 2010 provides for a monitoring and evaluation framework comprising project management performance criteria, external audit and reporting requirements, submission of progress reports, verification of project assets and value, and communication between stakeholders. Furthermore, performance audits on a PPP are left to the discretion of the Auditor General, and there are no provisions for the social and environmental auditing of PPPs, or for follow-ups on the Auditor General's report. It is only recently that the Parliamentary Standing Committee on Public Accounts followed up on the Auditor General's three qualified audit opinion reports, issued in 2007/2008, 2009/2010 and 2009/201, by means of an oversight visit to the PPPs in the Free State, the Northern Cape, and Limpopo (Parliamentary Communication Services, 2011).

A similar situation exists in Australia, where inquiries into PPPs in New South Wales (Public Account Committee NSW, 2006:45) revealed that there is little evidence of a systematic attempt to develop an empirically informed post-period evaluation capable of capturing and reporting on the degree of success of complicated, long-term partnerships.

The complexity of such projects results in many key performance areas making monitoring difficult to sustain. Governments are not yet prepared to manage performance systematically and comprehensively over the life of the project, but rather tend to rely on one-off reports or enquiries - usually when aspects of the PPP go wrong (Jonstone and Kouzmin, 2009; Johnston and Gudergan, 2009).

Also, although mention is made of dispute regulations, in the PPP Manual (2004), there is no provision for arbitration and for the resolution of disputes involving customers or users of PPP facilities. The United Nations Commission on International Trade Law (UNCITRAL) (2004) underscores the need for arbitration and for provision to be made for the resolution of disputes involving customers and users. It is only deduced from the PPP Manual (2004) that disputes are settled by mediation, by means of amicable negotiations, or in courts, but there is no mention of arbitration. One may infer that it is because the legislative framework for arbitration in South Africa, principally regulated by the South African Arbitration Act 42 of 1965, is widely considered to be outdated and in need of reform. United Nations Economic and Social Commission for Asia and the Pacific (UNESCAP) (2011) advocates that most dispute resolution mechanisms should be brought in line with international practices and requirements, given the expectation of large-scale investments from the foreign private sector.

\section{Failure to ensure value for money}

Value for money is an important requirement when deciding on whether to proceed with PPPs, and it is one of the key arguments for expanding it. It requires estimating the future financial and non-financial benefits of the procurement option, and its measurement involves discounting rates and risk transfer, and estimating future cash flows (Broadbent et al., 2004; Demirag, 2011). It is an aspect of performance, and can be defined in terms of the three Es: economy, efficiency and effectiveness (Glynm, 1985). Grimsey and Lewis (2004) define value for money as the optimum combination of costs, risks, completion time and quality for the entire life cycle, in order to meet public requirements. In the $\mathrm{UK}$, value for money is defined in terms of whether it has the right mix of cost, quality and flexibility quality (Robertson, 2008).

The Public Sector Comparator (PSC) is a theoretical model used in the UK and South Africa in assessing and comparing PPP options with traditional public procurement models, after which it is compared with bids from the private sector to evaluate any value-for-money benefits accruing from the PPP mechanism. Value for money is deemed to occur if the discounted cash flows from PPPs are less than those from PSC. Issues such as the PSC being more hypothetical in nature, the transparency of the PSC and the absence of full details regarding the calculation of the PSC have arisen over the use of the PSC (Grimsey and Lewis, 2005; Public Accounts Committed NSW Parliament, 2006; Ball, 2010). The desire to show that PPP deals are cheaper than PSC has led to manipulation of the underlying calculations and erroneous interpretations of the results (Corner, 2004:50). Nevertheless, as in other countries, there is no conclusive evidence in South Africa that PPPs actually reduce costs and enhance value for money. This is because of the history of high transaction costs, cost overruns, delays in service delivery, as well as long, complex negotiations surrounding PPPs.

\section{A lack of equitable risk allocation}

In the light of the growing incidence of public bailouts in PPPs, there are questions as to whether risk transfer actually occurs. Hodge, in evidence given during an inquiry into PPPs in New South Wales (Public Account 
Committee NSW Parliament, 2006:60), lamented the amateurish way in which public risk is presently determined. The common types of risk are technical risk, design and construction risk, operating and maintenance risk, revenue risk, financial risk, force majeure, legislative risk, political risk, environmental risk, uptake patronage risk and commissioning risk (Grimsey and Lewis 2002; Forerr, 2010). Murray (2007) observes that estimating traffic and revenue risk is more an art than a science, and that it has a tendency to go wrong. For example, the budget of the Gauteng Department of Roads and Transport for 2011/2012 included an estimated R259 million in "patronage guarantee costs" for Gautrain Rapid Rail Link concessionaires if the train did not attract enough passengers for the subsequent 9 months that it was due to be fully operational, and it was expected to rise to R360 million in the subsequent year (Flanagan, 2011). Paying this out every year will squeeze out other public transport projects, as it will consume about a third of the Gauteng roads and the transport budget (Campbell, 2011). Given that the government is bearing the demand risk, the question arises whether risks are actually transferred to the private sector, and whether the private sector does bear significant penalties when things go wrong. Another question that arises is whether the project becomes more a public than a private one, given the nature of public intervention. Therefore, contrary to the implicit assumption that substantial risk is transferred to the private sector by South African law (Treasury Regulation, 2004) in its definition of a PPP, this does not necessarily prove to be the case in South Africa.

Furthermore, the risk-transfer process at the contract appraisal stage is often subjective, and tends to be exaggerated, because it is difficult to identify, allocate and value risks (Froud and Shaoul, 2001). This is evident from the provision in the South African PPP Manual (2004), which stipulates that "budgets for major procurement projects have been prone to optimism bias." This means that there has been a tendency to budget for the best possible (often lowest cost) outcome, rather than the most likely. This provision will result in poor risk allocation, which in turn results in cost overruns.

\section{FUTURE PERSPECTIVES FOR ACCOUNTABILITY IN PPPS IN SOUTH AFRICA}

Given the above accountability challenges within the current PPP procurement model, it is clear that if the vision and effective delivery of PPPs are to be realised, several measures should be put in place to enhance accountability in the different stages of establishing PPPs. The following measures are examined in this section: appropriate accountability structures, ethical standards, stakeholder consultation, transparent procurement processes, access to information, anticorruption efforts, appropriate risk transfer, political leadership expertise and contract monitoring.

\section{Appropriate accountability structures}

There is a need for formal accountability mechanisms that criticise and complement government decisions and private sector actions, and keep the public informed. For example, in the UK, the public finance initiative has adopted contractual communal and managerial accountability structures as formal accountability processes in the different stages of its projects (Sinclair, 1995; Roberts, 2002; Shearer, 2002, Demirag and Khadaroo, 2011). Also, collaborative accountability structures will enhance trust and collaboration between public and private partners, since they are engaged in long-term integrated responsibilities that cannot as easily be severed as those in short-term contracts. Furthermore, market accountability structures will enable private parties to account to shareholders, business partners, insurers, investors, stockholders and competitors. A two-way contractual service document that clearly defines service expectations, output-based specifications and criteria for service evaluation, and that standardises communication methods will enhance contractual accountability (Kroukamp, 2004:38; 2010).

\section{Ethical standards}

Integrity is an important variable in enhancing accountability, a prerequisite for public trust and a keystone of good governance (Armstrong, 2005). Each party in the partnership should be subject to ethical values in the exercise of duty, and the provision of PPPs should be checked against ethical standards. As professionals, public and private officials should be answerable to each other through shared networks and collegial relationships. PPPs in South Africa should adhere to the Code of Practice for Empowerment in PPPs and the Code of Good Practice for Black Economic Empowerment in PPPs (PPP Manual 2004), and sanctions should be imposed for noncompliance. A code of conduct should be drafted, factoring the Nolan Committee's Seven Principles of Public Life (Chapman, 2000:230-231): These provide a valuable framework for evaluating the ethical behaviour of public officers. The code of ethics for PPPs should also be aligned to the constitutional ideals of professional ethics, efficiency, effectiveness, development orientation, impartiality, fair and equitable service delivery, public participation, accountability and transparency, human resource management and development, as well as representivity.

Adherence to international norms linked to accountability will also enhance transparency and the quality of public contracting. Forming part of these norms is the Integrity Pact developed by Transparency International. It contains an agreement that can be used by a government department and a bidder for a public sector contract, to the effect that they will abstain from bribery during the selection 
and implementation of the contract, and disclose all commissions and similar expenses paid in connection with the contract (Nepad Policy Focus, 2005). Another international initiative is the Extractive Industries Transparency Initiative (EITI), launched at the World Summit on Sustainable Development in Johannesburg, South Africa, in September 2002. This is a contract between governments, international organisations, companies, non-governmental organisations, investors, business and industrial organisations to increase transparency, avoid corruption and improve governance in transactions between governments and companies in the extractive industries (Aaronson, 2011). The Government of Cambodia, for example, has effectively protected workers' rights through collaboration between the International Labour Organisation and multinational firms through Better Factories Cambodia (BFC) (Wetterberg, 2011).

\section{Stakeholder consultation}

Consistent and clear communication with all stakeholders will build trust, encourage transparency and increase engagement. Flyvbjerg et al. (2003) observe that the most important way in which accountability can be enforced in the public sector is by governments initiating maximum public participation and discussion by all stakeholders through forums such as public hearings, independent peer reviews, scientific conferences, advisory committees, social surveys, citizen panels and other citizen initiatives. Authorities are reminded of the need to assure beforehand that the envisaged undertakings are in the public interest, and are acceptable to consumers and stakeholders, particularly when a PPP is being used to construct "large physical assets" (OECD, 2007:18).

\section{Transparent procurement process}

Notwithstanding the numerous pieces of legislation at the national and provincial levels emphasising the need for transparency, measures should be in place to ensure consistent and fair enforcement of these laws. A transparent and efficient procurement process will lower transaction costs and shorten the time taken in negotiating and completing deals (Cheung et al., 2009). For example, the selection of bidders, criteria applied for expenses and the tendering procedure should be subject to public examination and review (Beh, 2010). The Canadian system of procurement has been revised in favour of competition in the tendering process, judicial review of procurement decisions and limited preferred treatment for certain classes of suppliers (Atwood and Michael, 1996).

Also, given that the South African judiciary enjoys a degree of independence, it should be able to promote clear rules on the conflict of interests for the public sector and impose a legal constraint on government discretion during bidding processes (Atwood and Trebilcock, 1996). Although the media and civil society are already serving as effective counterweights in promoting accountability in PPPs, with the approval of the Protection of State Information Bill, there is a need to strengthen freedom of information laws to strengthen the media's watchdog role.

Accounting policies should enable the achievement of fiscal responsibility and transparency objectives. In the light of what has been attained in India (Comptroller and Auditor General of India, 2009), the principles and guidelines for auditing PPPs should be drawn from the International Organisation of Supreme Audit Institutions (INTOSAI) and customised to the South African context in ways that promote transparency, accountability and value for money. A serious step has been taken towards enhancing compliance monitoring and improving transparency and accountability in supply chain management, to government accounting officers on spheres of government on all competitive bids exceeding R5 million, through issuance of National Treasury Instruction Note in terms of Section 76 (4) (c) of the Public Finance Management Act (PFMA) (National Treasury, 2011).

\section{Expand access to information}

Although the need to protect trade secrets and negotiating positions does require keeping some documents out of the public domain, the lack of appropriate and rigorous public scrutiny makes it difficult for the public to identify hidden cost that private parties transfer to the government in the long run. The confines of "commercial-in-confidence," which entails designating information that must not be made available to the public, should be lifted to allow the provision of PPP documents in a timely manner. Similar to what has been attained in British Columbia (TD Economics Special Report, 2006), a balance should be struck between satisfying the public's desire to know and the company's desire for commercial confidentiality.

In Australia, PPP information is published within 3 months of signing a contract, and includes a brief summary of the contract content, a report on value for money, details on assets to be transferred to the private sector, total cost and basis for future changes in price, contract renegotiation provisions, risk-sharing details in the construction and operational stages, guarantees made by both parties and details of the PSC (OECD, 2000). Forrer et al. (2010) suggest that PPP disclosure standards should include information on a comparison of the cost and non-cost advantages and disadvantages of the relevant alternative, the use of appropriate comparators, requests for proposals, the terms of contract, the monitoring and auditing regime, ongoing access to an auditor and relevant information on the private sector partners. The South African Parliamentary Standing Committee on Public Accounts should regularly disclose revenue figures from concessions that are awarded. 
Anticorruption efforts should remain a continuous process

There is no doubt that the South African government is taking serious steps to combat and prevent corruption through its various anticorruption activities. Fighting corruption is one of the 12 outcomes that the government has identified as its key focus. South Africa is a signatory to the African Union (AU) Convention on Preventing and Combating Corruption of 2003. The Minister of Finance has established the Multi-Agency Working Group (MAWG) to coordinate efforts and to investigate corruption related to supply chain management practices. In addition, there are several key Acts addressing corruption, for example, the Promotion of Administrative Justice Act (PAJA) of 2000, the MFMA (2003), and the Prevention and Combating of Corrupt Activities Act 12 of 2004. However, the fact that corruption in procurement continues to increase despite all these measures means that the government needs to reconsider and intensify its efforts by addressing the issues and causes of corruption, and re-examining and reinforcing anticorruption structures and institutions. A culture of integrity, transparency and accountability should be promoted amongst public officials. Center for International Private Enterprise (CIPE, 2011) acknowledges the role of the private sector and strong, balanced institutions and incentive structures that reward honesty and transparency and punish bribery and abuse of public funds. Anticorruption initiatives such as corporate governance, engaging private businesses in anticorruption efforts, and advocating institutional reform are crucial (CIPE, 2011). Creating an atmosphere for healthy dialogue with the private sector is also essential to ensure that policies designed to curb corruption in PPPs address the real needs of the business community.

\section{Appropriate risk transfer}

The bottom line is to ensure that defined risk is allocated optimally, rather than maximising risk transfer. In the UK and Australia, risk is allocated to the party that can best bear it at the lowest cost (Ball, 2011). Therefore, references to substantial financial, technical and operational risks having been transferred to the private sector in the South African definition of PPPs need to be clarified, because it is obvious that the government will always bear some of the risk. According to the current Minister of Economic Development, future PPPs will have to embrace an "equitable risk transfer" to the private sector, as opposed to models deployed in the recent past that left the public sector bearing the bulk of the risk burden (Creamer, 2012). It is important for these risks to be evaluated by the public and the private bidder throughout the entire life of the project, and particular attention should be paid during the procurement process to make free risk allocation possible (Cheung et al., 2009). The UK National Audit Office (2001) notes that there is no standard way of establishing value for money in the PPP context, and that procurers need to design their methodologies while bearing ways of assessing performance, pricing and feedback from users in mind. Other sophisticated systems of risk transfer worth emulating are the South Australian "Monte Carlo" system (South Australia Department of Treasury and Finance Project Analysis Branch, 2004), and the UK Outline Business Case $(\mathrm{OBC})$, published in the Value for Money Assessment Guidance (HM Treasury of the UK, 2006).

It is also very important to clearly ascertain the affordability of a project in terms of its current and expected future risk. Systematic risk management allows early detection, and enables PPP stakeholders to introduce risk mitigation policies (Sciulli, 2010). PPPs require proactive expert analysis of the different types of risk. For example, a public agency entering a partnership should devise a plan to mitigate the public impact of a service interruption as a result of failure by either party to deliver due to forces beyond their control (Forre et al., 2010). In British Columbia, five steps were used to manage risk in the development of a highway PPP. These were: risk planning, risk identification, risk analysis, risk response and development monitoring and controlling (Coates et al., 2008).

\section{Political will}

Most of the successful projects in Africa have been the result of strong political support and commitment. Two examples of such projects are the construction of the N4 toll road, promoted by the then Mpumalanga Premier Mathews Phosa, and the provision of water and electricity in Gabon (Nepad Policy Focus, 2005). A firm political will and commitment towards PPP help to maintain the momentum of the partnership and ensure that goals are met in the agreed-upon time frame, and that those responsible for missing deadlines are held accountable.

The ultimate attraction of PPPs is not satisfying the demand for political collaboration with a private party, but increasing the efficiency, innovation and value for money through good procurement management practices. Therefore, it is crucial for the government, as the public partner, to lend genuine legitimacy and credibility to the existing legislation by means of strong implementation. This may be reflected in its role in regulating and evaluating PPPs in ways that best serve the public interest, and in administering the contracts equitably and transparently.

The United Nations Millennium Project (UNMP, 2005) reports on a practical plan to achieve the millennium development goals (MDG). It suggests firm political leadership and strong government commitment in order to realise the goals of improving public investment and capacity building. Commitment to PPPs should not be influenced by short-term gains such as earning another electoral term, and should be weighed against the long-term costs. Political stability is important, and the project should 
be able to continue, even when government changes hands. A good example is the Gautrain Rapid Rail Link, which has so far survived three elections and five cabinets.

\section{Contract monitoring}

The development of performance management measures and monitoring systems will strengthen accountability in PPPs (Forrer et al., 2010; Sciulli, 2010). Recognising that the responsibility for contract management will extend throughout the life cycle of the contract and not end once the contract has been awarded should be the point of departure (New Zealand Office of the Auditor-General, 2006b: 84). PPP initiatives should unfold within a quality assurance framework containing a streamlined monitoring mechanism and feedback system, and its implementation should be scrutinised to ensure that the objectives of reporting systems are met. Incentive structures can also make the difference between a PPP that succeeds and one that fails (Goldsmith and Eggers 2004:130). For example, private finance initiative contracts in the UK are monitored internally by the public sector procurement agency through monthly operational review meetings and quarterly strategic review meetings, while the external monitoring of private finance initiative contracts is carried out by parliamentary institutions such as the UK National Audit Office and the Audit Commission, after which reports are tabled in the Public Accounts Committee and are generally made available to the public (Dimirag et al., 2004). It is important for the Auditor General's process to be taken to its logical conclusion and for those held accountable being disciplined appropriately. English and Guthrie (2003) highlight the importance of parliamentary scrutiny of PPPs. The South African PPP Manual should consider internal and external monitoring initiatives and structures from the inception of contracts though their implementation and development. Some examples of these monitoring structures are contractual and managerial accountability structures, parliament, civil society organisations, the mass media, international organisations and self-monitoring structures.

The monitoring structures within the Gautrain Rapid Rail PPP provide an example of an efficient monitoring system. The GMA is required to ensure proper implementation of the concession agreement on behalf of the government, while the special purpose vehicle set up for the project is responsible for ensuring the management of the construction company. The successful resolution of the dispute between the GMA and the Gautrain Construction Company was due to the efficient operation of the monitoring system. There is also an Independent Certifier attached to the Gautrain project, who is supposed to assess whether the milestones of Gautrain have, in fact, been achieved, and to make recommendations to the Provincial Government.

Also, the South African National Road Agency (Sanral), established by the Department of Transport and Public
Works to manage major projects in the private sector, has become an internationally recognised centre of expertise for PPPs in roads. Although its proposal of the "user pays" principle for the $185 \mathrm{~km}$ of road upgraded under the Gauteng Freeway Improvement Project (GFIP) in 2011 has resulted in an ongoing debacle, a similar sector-specific implementing agency approach to monitor PPPs from their inception through their development stage should be encouraged.

\section{CONCLUSION}

This paper has examined some accountability challenges in PPP as they are experienced in South Africa and has provided some perspectives on enhancing accountability. A key implication of this paper is that if PPPs are to be used as a major innovative policy tool that will remedy the problem of inertia in traditional public service delivery and deal with its deeply rooted socioeconomic, political, fiscal and societal problems, then accountability in PPPs will be critical. Therefore, the major onus rests on government as the major role-player in PPPs to lend genuine legitimacy and credibility to the existing legislation through strong implementation. It should also apply effective external and internal checks to enhance the credibility of PPPs as a tool for improving service delivery. Accountability in PPPs will become effective, should appropriate accountability structures and anticorruption measures be put in place, and should effective mechanisms to assure stakeholder consultation, transparent procurement processes, open access to information, contract monitoring and appropriate risk transfer be activated. The ultimate attraction of PPPs is not satisfying the demand for public collaboration with the private sector, but increasing efficiency and innovative service delivery, and ensuring value for money through good practices in procurement management.

\section{FOOTNOTE}

${ }^{1}$ These are public management policies that have been applied since the 1980s and that aim to modernise the public sector and render it more effective by emphasising the centrality of the citizen and of accountability for results.

\section{REFERENCES}

Aaronson, S. 2011. Limited partnership: Business, government, civil society, and the public in the extractive industries transparency initiative (eiti). Public Administration Development, 31, 25-36.

Acar, M., Chao, G., and Kaifeng, Y. (2008). Accountability when hierarchical authority is absent: Views from public-private partnership practitioners. American Review of Public Administration, 38, 271-90.

Aiello, J. (2010). A treasury view on South Africa's PPPprogramme. Presentation: Senior Project Advisor, PPP Unit, National Treasury. [Online] Available from: k.cput.ac.za/cgi/ viewcontent. cgi?filename $=0$ andarticle $=1024$ [Last accessed on 16 March 2012].

Armistead, C. and Pettigrew, P. (2004). Effective partnerships: Building a sub regional network of reflective practitioners. International Journal of Public Sector Management, 17, 571-85.

Armstrong, A. (2005). Integrity, transparency and accountability 
in public administration: Recent trends, regional and international developments and emerging issues. United Nations Economic and Social Affairs [Online]. Available from: http://unpan1.un.org/intradoc/ groups/public/documents/un/unpan020955.pdf [Last accessed on12 May 2012 ].

Batho Pele Handbook (2005). A service delivery improvement guide: Association for Public Administration and Management. [Online] Available from: http://www.dpsa.gov.za/documents/gics/bphb/BathoPeleHandbook. pd [Last accessed 11 June 2011].

Beh, L. (2010). Development and distortion of Malaysian public-private partnership-Patronage, privatized profit and pitfalls. Australian Journal of Public Administration, 69 (S1): S74-84.

Behn, R. (2001). Rethinking democratic accountability. Washington, DC: Blagescu, M., de las Casas, L., and Lloyd, R. (2005). Pathways to accountability. The GAP Framework, One World Trust: London.

Blake, N. (2004). Pros and cons of public-private partnerships. Australian Nursing Journal, 11, 15.

Bovaird, T. (2004). Public-private partnerships: From contested concepts to prevalent practice. International Review of Administrative Science, 70, 200-14.

Bovens, M. (2007). Analyzing and assessing accountability: A conceptual framework. European Journal of Law, 13, 447-68.

Bovens, M. (2010). Two concepts of accountability: Accountability as a virtue and as a mechanism. West European Politics, 33 (5), 946-96.

Bovens, M. and Schillemans, T. (2009a). Publiekeverantwoording: Begrippen, vormen en beoordelingskaders. In M. Bovensand, T. Schillemans (Eds.). Handboek publiekeverantwoording, (pp. 19-34), Den Haag: Lemma.

Brinkerhoff, D. and Brinkerhoff, J. (2011). Public-private partnerships: Perspectives on purposes, publicness, and good governance. Public Administration and Development, 31, 2-14.

Brinkerhoff, J. (2007). Partnership as a means to good governance: Toward an evaluation framework. In partnerships, governance and sustainable development: Reflections on theory and practice. In P. Glasbergen, F. Biermann, A. Mol (Eds.). Edward Elgar Publishers: Cheltenham, UK and Northampton, MA; 68-89.

Broadbent, J. (2003b). The Private Finance initiative in the UK. Critical Perspectives on Accounting, 14, 23-48.

Burger, P. (2004). The dedicated PPP unit of the South African National Treasury [Online] Available from: http://www.oecd.org/ dataoecd/50/54/37147218.pdf [Last accessed on 12 April 2012 ].

Campbell, N. (2011). Democratic alliance: Member of parliament. [Online] Available from: http://www.politicsweb.co.za/politicsweb/view/ politicsweb/en/page71619? oid=242040andsn = Marketingweb + deta il [Last accessed on 06 August 2011 ].

Chapman, R. (2000). Ethics in public service for the new millennium. Vermont: Chatham House.

Cheung, E., Albert, P. and Stephen, K. (2006). Enhancing value for money in public-private partnership projects: Findings from a survey conducted in Hong Kong and Australia compared to findings from previous research in UK. Journal of Financial Management of Property and Construction, 14, 7-20.

Clifton, C. and Duffield, C. (2006). Improved PFI/PPP service outcomes through the integration of alliance principles. International Journal of Project Management, 24, 573-86.

CIPE. (2011). Center for International Private Enterprise. Tool kit combating corruption: A private sector approach. [Online]. Available from: http://www. cipe.org/sites/default/files/publication-docs/Anti-CorruptionToolkit0308. pdf [Last accessed in May 2012 ].

Corner, D. (2006). The United Kingdom Private Finance Initiative: The challenge of allocating risk. OECD Journal on Budgeting, 5, 37-55.

Coulson, A. (2005). A plague on all your partnerships: Theory and practice in regeneration. International Journal of Public Sector Management, $18,151-63$.

Creamer, T. (2011). Tighter tender rules issued in bid to combat fraud, boost transparency. Engineering News [Online]. Available from: http://m.engineeringnews.co.za/article/ tighter-tender-rules- issued-inbid-to-combat-fraudboost-transparency-2011-05-31 [Last accessed on
30 July 2011].

Creamer, T. (2012). Future PPP model must balance public, private risk more equitably. Engineering News. [Online]. Available from: http:// www.engineeringnews.co.za// future-ppp-model-must- balancepublic-private-risk-more- equitably-2012-05 [Last accessed on 04 May 2012].

Dach, W. (2010). Financial crises and South Africa's PPP Unit: The demerger of regulatory and advisory roles, greater independence on Treasury. Presented at PPP Days by the Head of PPP Unit at Treasury, William Dachs.

Deleon, L. (1998). Accountability in a reinvented government. Public Administration, (76), 539-58.

Deloitte and Touche Research. (2006). Closing the infrastructure gap: The role of public-private partnerships. [Online]. Available from: http:// www.deloitte.com/assets/Dcom-Shared\% 20Assets/Documents/dtt_ps closinggap061307.pdf [Last accessed on 09 April 2012].

Demirag, I. and Khadaroo, I. (2011). Accountability and value for money: A theoretical framework for the relationship in public-private partnerships. Journal of Management and Governance, (15), 271-96.

Demirag, I., Dubnick M., and Khadaroo, M. (2004). A framework for examining accountability and value for money in the UK's Private Finance Initiative. Journal of Corporate Citizenship (15), 63-76.

Dowdle, M. (2006). Public accountability: Conceptual, historical, and epistemic mappings.In M. Dowdle, Public Accountability: Designs, Dilemmas and Experiences, 1-26. Cambridge: Cambridge University Press. Dropper, D. (2011). Toll fee bargaining isn't over yet. August 18, page 6, Pretoria news.

Dubnick, M. and Justice, J.B. (2002). But can you trust them to be ethical? Paper presented to the $63^{\text {rd }}$ annual conference of the American Society for Public Administration, March 23, Phoenix.

Dubnick, M. And Romzek, S.B. (1991). American public administration, politics and management of expectations. New York: Macmillan.

Dubnick, M. (1998). Clarifying accountability: An ethical theory framework. In Charles, S., Noel, P., and Bois, C.A. (Eds.). Public sector ethics: Finding and implementing values. Leichhardt, NSW, Australia: The Federation Press/Routledge.

Dubnick, M. (2003). Accountability and ethics: Reconsidering the relationships. International Journal of Organization Theory and Behavior, 6, 405-41.

Dubnick, M. (2005). Accountability and the promise of performance: In search of the mechanisms. Public Performance and Management Review, 28, 376-417.

Edward, P., Shaoul, S., and Arblaster, L. (2004). Evaluating the operations of public financial initiatives in roads and hospitals. London: The Association of Chartered Certified Accountants.

English, L.M. and Guthrie, J. (2003). Driving privately financed projects in Australia: What makes them tick? Accounting, Auditing and Accountability Journal, 16, 493-511.

Farlam, P. (2005). The South African Institute of International Affairs: Nepad Policy Focus Series Working Together Assessing Public Private Partnerships in Africa. [Online]. Available from: http://www.oecd.org/ investment/investmentfordevelopment/34867724.pdf [Last accessed on 15 November 2012].

Flanagan, L. And Serrao, F. (2011). Gautrain hidden millions:, shock for the tax payer. 21 June, Pretoria: The Star Newspaper.

Flanagan, L. (2011). Democratic alliance fight for transparency in Gautrain's costs. June 22, Pretoria: The Star Newspaper.

Flinders, M. (2005). The politics of public-private partnerships. British Journal of Politics and International Relations, 7, 215-39.

Flyvbjerg, B., Bruzelius, N., and Rothengatter, W. (2003). Megaprojects and risk: An anatomy of ambition. Cambridge, UK: Cambridge University Press. Forrer, J., Kee, J.E., Newcomer, K.E., and Boyer, E. (2010). Public-private partnerships and the public accountability question. Public Administration Review, 70 (3), 475-84. [Online]. Available from: http://unpan1.un.org/ intradoc/groups/public/documents/UN/UNPAN005172.pdf [Last accessed on 23 February 2013 ].

Froud, J. And Shaoul, J. (2001). Appraising and evaluating PFI for NHS hospitals. Financial Accountability and Management, 17 (3), 191-297. 
Fussell and Beresford. (2009). Public-private partnerships: Understanding the Challenge. Centre for Civic Governance, Columbia, $2^{\text {nd }}$ ed.. Available from: http://www.civicgovernance.ca/files/ uploads/columbiap3_eng_ v8-webpdf.pdf [Last accessed on 03 June 2011].

Grimsey, D. and Lewis, M. (2002). Evaluating the risk of public-private partnership for infrastructure projects. International Journal of Project Management, 20, 107-18.

Grimsey, D. and Lewis, M. (2004). Public-private partnership: The world wide revolution in infrastructure provision and project finance. Edward Elgar: Cheltenham.

Grimsey, D. and Lewis, M. (2005). Are public-private partnerships value for money? Evaluating alternative approaches and comparing academic and practitioner views. Accounting Forum, 29, 345-78.

Hanekom, S., Rowland, R., and Bain, E. (2004). Key aspects of public administration. Johannesburg: Southern Book Publishers Ltd.

Heald, D. and Lewis, M. (2003). Value for money test and accounting treatment in PFI schemes. Accounting Auditing and Accountability Journal, 16, 342-71.

Heymans, C. and Schur, M. (1999). National and provincial PPPs: Issues of supervision and accountability. Development Southern Africa, 16 (4), 607-22.

Hodge, G. and Coghill, K. (2007). Accountability in the privatized state. Governance, 20, 675-702.

Hodge, G. and Greve, C. (2005). The challenge of public-private partnerships: Learning from International experience. (pp. 81-94) UK: Edward Elgar, Cheltenham.

Institute of Policy Research. (2001). Building better partnerships: Executive summary [Online]. Available from: http://www.ippr.org/uploadedFiles/ flagshipprogrammes/BBP\%20Exec\%20TG\%20Edit.pdf [Last accessed on 09 June 2011].

Jones, G. and Stewart, J. (2009). New development: Accountability in public private partnership. The case of local strategic partnerships. Public Money and Management, 29, 59-64.

Johnston, J. And Gudergan, S. (2009). Ethical leadership in public-private partnerships: Learning from an Australian great controversy: In J. Raffel, P. Leisink, and T. Middlebrook, (Eds.). Public Sector leadership: International challenges and perspectives, 276-93.: US, Edward Elgar.

Johnston, J. and Kouzmin, A. (2010). Addressing governance accountability and performance monitoring issues in partnerships: Can Infrastructure Australia provide a strategic response? Public Administration Quarterly, 34, 513.

Kearns, K. (1994). The strategic management of accountability in Nonprofit organizations: An analytical framework. Public Administration Review, 54, 185-92.

Kee, J. and Newcomer, E. (2008). Transforming public and nonprofit organizations: Stewardship for leading change. McLean: VA: Management Concepts.

Kelman, S. (2001). Discussion paper on procurement issues in South Africa that affect growth and development. Harvard University, JFK School of Government.[Online]. Available from: $h$ ttp://www.treasury.gov. za/publications/other/growth/06-Procurement\%20and\%20BEE/01- [Last accessed on 12 November 2012].

Kolbila, C.J., Mills, R.M., and Zia, A. (2011). Accountability in governance networks: An assessment of public, private, and nonprofit emergency management practices following hurricane Katrina. Public Administration Review, 71, 210-20.

Kroukamp, H. (2004). Public-privatepartnerships. Management Today, 20, 28-9.

Levinsohn, D. and Reardon, D. (2006). Municipal PPP projects in South Africa: Obstacles and opportunities. PPP Quarterly. [Online]. Available from: http://www.ip3.org/municipal-ppp-projects-in-South- AfricaObstacles-and-Opportunities.html [Last accessed on 09 March 2012].

Mail and Guardian. (2012). The Editorial: Massive secret payoffs greasing the Gautrain wheels. [Online]. Available from: http://mg.co.za/ article/2012-05-31-first-evidence-of-payoffs-in-contract-for-gautrain [Last accessed on 15 November 2012].

Mashaw, J. (2006). Accountability and institutional design: Some thoughts on the grammar of governance. In Public accountability: Designs dilemmas and experiences. In M.W. Dowdle, (Ed.). (pp. 115-6), Cambridge: Cambridge University Press.
Mayston, D. (1999). The Private Finance Initiative in the National Health Service: An unhealthy development in new public management? Financial Accountability and Management, (15) 3, 4-249.

Mitchell, D. (2007). Capacity development for partnerships in South Africa: Increasing service delivery through partnerships between private and public sector. Report on findings of needs assessment, Fakisandla Consulting. [Online]. Available from: http://www.iblf.org/./partnership/./3EOC 2C8D25C2451EBD648E97DC6C2906. ashx [Last accessed on 04 June 2012].

Mörth, U. (2007). Public and private partnerships as dilemmas between efficiency and democratic accountability: The case of Galileo. Journal of European Integration, 29, 601-17.

Mulgan, R. (2000). Accountability: An ever-expanding concept? Public Administration, 78, 555-73.

Mulgan, R. (2003). Holding power to account. New York: Palgrave.

Murray E. (2007). Public-private partnership in transportation: The case of Washington State. Vilkalpa, 32, 53-9.

National Audit Office. (2001). Managing the relationship to secure successful partnership in Public Finance Initiative projects. Report of Comptroller and Auditor General. HC 375 session 2001-2002, London: The stationary office.

National Treasury. (2007). Public-Private Partnership Unit, National Treasury.

National Treasury. (2011). Department of National Treasury South Africa. [Online]. Available from: http://oag.treasury.gov.za/ Publications/10.\%20Practice $\% 20$ Notes/For $\% 20$ fin $\% 20$ year $\% 20$ $2011-12 / 20110531 \% 20$ Instruction\%20Note $\% 2032 \% 20$ - 20 Enhancing $\% 20$ Compliance $\% 20$ Monitoring $\% 20$ SCM.pdf [Last accessed on 09 May 2011].

National Treasury. (2011). Department of National Treasury South Africa. [Online]. Available from: http://www.treasury.gov.za/divisions/sf/ sc/PracticeNotes/default.aspx [Last accessed 201109 May May].

National Treasury. (2004). Public-private Partnership Manual. National Treasury.

National Treasury. (2009). Public-private Partnership Unit, National Treasury.

Nepad Policy Focus Series. (2005). Working together assessing public-private partnership. In South African Institute of International Affairs (SAII's), In P. Farlam, (Ed.). Nepad Governance Project. Pretoria: Funded by Royal Netherlands Embassy.

Newberry, S. and Pallot, J. (2003). Fiscal responsibility: Privileging public-private partnership in New Zealand. Accounting, Auditing and Accountability Journal, 16, 467-92.

Ngalwa, S. and Maphumulo, S. (2011). Madonsela fights back. July 10, page 1. Pretoria: Sunday Times.

Nova Scotia Cooperation Agreement. (1996). Strategic public-private partnership guide to Nova Scotia Municipalities.[Online]. Available from: http://www.gov.ns.ca/snsmr/muns/fin/pdf-ppp/[Last accessed on 18 June 2011].

OECD. (2007). Organization for Economic Cooperation and Development: Principles for private sector participation in infrastructure. [Online]. Available from: http://www.oecf.prg/dataoecd/41/33/38309896.pdf [Last accessed on 21 August 2011].

Osborne, S.P. (2000). Public-private partnership. Theory and practice and International perspective. London: Routledge.

Parliamentary Communication Service. (2011). Business of parliament. [Online]. Available from: http://www.parliament.gov.za/live/ content.php?ltem_ID =1595 [Last accessed on 21 August 2011].

Pollitt, M. (2005). Learning from UK Private Finance Initiative experience, (pp. 207-30). In G. Hodge and C. Greve (Eds.). The challenge of public-private partnerships. Cheltenham, UK: Edward Elgar.

Public Accounts Committee NSW Parliament. (2006). Inquiry into Public-Private Partnerships Report No. 159. [Online]. Available from: http://www.parliamentnsw.gov.au/publicaccounts [Last accessed on 10 May 2011].

Public Accounts Committee Publications. (2011). Public Finance Initiative: Housing and hospitals. Fourteenth Report of Session 2010-11. [Online]. Available from: http://www.publications.parliament.uk/pa/cm201011/ cmselect/cmpubacc/631/63102.htm [Accessed on 15 May 2011]. 
Public Finance Management Act No. 1 of 1999. [Online]. Available from: http://www.wrc.org.za/downloads/legislature/PFMA1-99.pdf [Last accessed on 03 June 2011].

Public-private Partnership Quarterly 11. (2003). Finance Minister serious about making public-private partnership work. South Africa: Pretoria.

Public-private Partnership Manual. (2004). National Treasury. South Africa: Pretoria.

Public-private Partnership Manual. (2007). National Treasury. South Africa: Pretoria.

Public-private Partnership Quarterly 10. (2003). Unpacking standardised public-private partnership provisions., South Africa: Pretoria.

Reeves, E. (2011). The only game in town: Public-private partnership. The Economic and Social Review, 42, 95-111.

Rein, M. and Stott, L. (2009). Working together: Critical perspectives on six cross-sector partnerships in Africa. Journal of Business Ethics, (90), 79-89.

Robert, A. 2002. Closing the window: Public service restructuring and the weakening of public of freedom of information law. Salem Papers. [Online]. Available from: http://www.inpuma.net [Last accessed on 28 April 2011]. Robertson, J. (2008). Chief Economist and Director, National Audit Office. Personal interview, London, June 26.

Robinson, H. and Scott, J. (2009). Service delivery and performance monitoring in Public Finance Initiative/Public-private partnership projects. Construction Management and Economics, 27, 181-97.

Romzek, B. and Dubnick, M. (1987). Accountability in the public sector: Lessons from the Challenger tragedy. Public Administration Review, 47, 227-38.

Schillemans, T. (2008). Accountability in the shadow of hierarchy: The horizontal accountability of agencies. Public Organization Review, 8, 175-94. Sciulli, N. (2010). Building a framework for public-private partnership research. International Review of Business Research Papers, 6, 367-81.

Scott, C. (2000). Accountability in the Regulatory State. Journal of Law and Society, 27, 38-60.

Scott, C. (2006). Spontaneous accountability: Public accountability designs dilemma and experiences, by M. W. Dowdle, (pp. 174-94), Cambridge: University Press.

Sedisa, K. (2008). Public-private partnership in the provision of secondary education in Gaborone city area of Botswana. Doctor of Public Administration at the University of South Africa, Unpublished thesis.

Siddiquee, N. (2011). Rhetoric and reality of public-private partnerships: Learning points from the Australian experience. Asian Journal of Political Science, 19, 129-48.

Sinclair, A. (1995). The chameleon of accountability: Forms and discourses. Accounting, Organisations and Society, 20, 219-37.

State of the Public Service Report. (2005). Bracing the public service for sustained, effective service delivery based on BathoPele. Commission House, Arcadia: The Government Printer, South Africa.

Stephen, J. (2005). Fears Gautrain will be a large, expensive white elephant. November 9, Johannesburg: The Star.

Stewart, J. (1984). The role of information in public accountability: In A.G. Hopwood and C.R. Tomkins (Eds.). Issues in Public Sector Accounting. Oxford: UK: Philip Allan.

Stone, B. (1995). Administrative accountability in Westminster democracies: Towards a new conceptual framework. Governance, (8) 1, 505-26.

Swart, W. (2011). Gautrain security firm directors quit. August 21, Pretoria: Sunday Times.
Tati, G. (2005). Public-private partnership (PPP) and water-supply provision in urban Africa:The experience of Congo-Brazzaville. Development in Practice, (15)316-324.

TD Economic Special Report Bank Financial Group. (2006). Creating the winning conditions for public-private partnerships (P3s) in Canada. [Online]. Available from: http://www.td.com/economics/special/ db0606_p3s.pdf [Last accessed on 201112 June June].

Tennyson, R. (2003). The partnering toolbox. London: International Business Leaders Forum.

The Constitution of the Republic of South Africa, Act 108 of 1996. [Online]. Available from: http://www.acts.co.za/ constitution-of-the-republic-of-south-africa-act-1996// [Last accessed on 21 August 2011].

The Sun. (2009). PAC to Summon Ex Ministers. 2 July, Editorial.

Thomson, S. (2005). Investment for African development: Making it happen NEPAD/OECD investment initiative. Imperial Resort Beach Hotel Kama Hal, Entebbe, Uganda. [Online]. Available from: http://www.oecd.org/ dataoecd/29/45/34843203.pdf [Last accessed on 06 April 2012].

Treasury Regulation 16. (2004). Public-private partnerships. Issued in terms of the Public Finance Management Act, 1999, 16 January, Gazette No. 25915. UNDP. (2004). United Nation Development Program. Anti corruption Practice Note [Online]. Available from: http://www.uneca.org/itca/ governance/Documents/Anti\%20Corruption $\% 20$ Note $\% 20$ FINAL $\% 20$ VERSION\%20031704.pdf [Last accessed on 12 November 2012].

UNECHE. (2008). United Nations Economic Commission for Europe: Guidebook on promoting good governance in public-private partnership. Geneva: United Nations University Press.

UNMP. (2005). United Nations Millennium Project: Investigating report. Practical plan to achieve millennium development goals. [Online]. Available from: http://www.unmillenniumproject.org [Last accessed on 29 August 2011].

Van der Merwe, J. (2007). Project Leader, Gautrain Management Agency. Gauteng Provincial Government. [Online]. Available from: http://www.saicerailwayandharbour.co.za/symposium2007/14. Jack\%20van\%20der\%20Merwe.pdf [Last accessed on 15 August 2011].

Venter, I. (2011). Transport society voices support for user-pays principle. Engineering News. [Online]. Available from: http://www. engineeringnews.co.za/article/transport-society-voices- support-foruser-pay-principle-2011-07-08 R [Last accessed on 30 August 2011].

Walker, R.G. (2003). Public-private partnership: Form over substance. Australian Accounting Review, 13, 55-9.

West, E. (2003). First R and won't duck. Maharaj Report. August 1, Business Report.

Wetterberg, A. (2011). Public-private partnership in labor standards governance: Better factories Cambodia. Public Administration and Development, 31 (1), 64-73.

Willems, T. and Dooren, W. (2011). Lost in diffusion? How collaborative arrangements lead to accountability. International Review of Administrative Law, 77, 505-30.

How to cite this article: Fombad MC. Accountability challenges in public-private partnerships from a South African perspective. Afr J Bus Ethics 2013;7:11-25

Source of Support: Nil, Conflict of Interest: None declared

\section{AUTHOR}

Madeline Fombad obtained a PhD from the University of Pretoria at the Department of Information Science with specialisation on Knowledge Management in 2010. She obtained a Masters degree in Library and Information Studies in 2002, a Postgraduate Diploma in Guidance and Counseling at the University in 1996 and a Masters Degree in Law at the University of Yaoundé Cameroon. She did her postdoctoral studies at the Collaborative Governance and Partnerships Research Programme at the Institute for Corporate Citizenship UNISA. Her research areas are governance and accountability, knowledge management, public-private partnership, climate change, health governance and stakeholder management. 
Reproduced with permission of the copyright owner. Further reproduction prohibited without permission. 